\title{
Calcitonin Gene-related Peptide Is a Stimulator of Renin Secretion
}

\author{
Armin Kurtz," Roman Muff," Walter Born," Jan M. Lundberg," Britt-Inger Millberg," Markus P. Gnädinger," \\ Dominik E. Uehlinger," Peter Weidmann," Tomas Hökfelt,' and Jan A. Fischer" \\ ${ }^{*}$ Physiologisches Institut, University of Zürich, CH-8057 Zürich, Switzerland; ${ }^{\ddagger}$ Research Laboratory for Calcium Metabolism, \\ Departments of Orthopedic Surgery and Medicine, University of Zürich, CH-8008 Zürich, Switzerland; Departments of ${ }^{\S}$ Pharmacology \\ and 'Histology, Karolinska Institute, Stockholm S-10401, Sweden; and "Medizinische Poliklinik, Universitätsspital,
}

Bern CH-3010, Switzerland

\section{Abstract}

Calcitonin gene-related peptide (CGRP) was found to stimulate renin secretion in vivo in normal human volunteers. Moreover, CGRP stimulated the release of renin in vitro from isolated rat renal juxtaglomerular cells (half-maximal effective concentration [EC $\mathrm{ES}_{\mathbf{5}}$ ] $100 \mathrm{nM}$ ) concomitant with stimulation of cAMP production $\left(E_{50} 60\right.$ nM). Immunoreactive CGRP was recognized in rat renal cortical nerve fibers, and intact rat CGRP was identified in extracts of the rat renal cortex. Because CGRP containing sensory nerve fibers are seen in the region of the juxtaglomerular apparatus, it would seem that the release of CGRP from these afferent nerves may be involved in the physiological control of renin secretion.

\section{Introduction}

Calcitonin gene-related peptide (CGRP) ${ }^{1}$ (1) is a 37 -amino acid polypeptide that results from the tissue-specific processing of the primary RNA transcript of the calcitonin gene (1-4). CGRP was identified in the central nervous system (CNS), but also in thyroid $C$ cells $(2,3,5)$. As a neuropeptide, CGRP is considered to act as neurotransmitter or neuromodulator in the CNS and peripheral nervous system $(6,7)$. The physiological roles of CGRP remain to be clarified. Recent observations are consistent with a function of CGRP in cardiovascular regulation. CGRP thus causes relaxation of small arteries and has positive chronotropic and inotropic effects on the hearts of man and experimental animals (8-12).

Several vasoactive hormones affect the humoral control of circulation by changing the release of renin from renal juxtaglomerular cells. Vasoconstrictive hormones generally inhibit renin secretion, whereas most vasodilating hormones stimulate release (13). So far, it remains to be demonstrated whether CGRP, which is a potent vasodilator, also stimulates renin secretion directly.

Address reprint requests to Dr. Armin Kurtz, Physiologisches Institut der Universität-Zürich-Irchel, Winterthurerstrasse 190, CH-8057 Zurich, Switzerland.

Received for publication 6 October 1987 and in revised form 7 March 1988.

1. Abbreviations used in this paper: CGRP, calcitonin gene-related peptide; $\mathrm{EC}_{50}$, half-maximal effective concentration; IBMX, 3-isobutyl-1-methyl xanthine; JEG, juxtaglomerular epitheloid.

J. Clin. Invest.

(C) The American Society for Clinical Investigation, Inc.

0021-9738/88/08/0538/06 $\$ 2.00$

Volume 82, August 1988, 538-543
In human tissues, CGRP has been identified in two forms, I and II (or $\alpha$ and $\beta$ ), which differ in three amino acids (3-5). CGRP-I and -II were equally effective in stimulating the contractility of isolated human auricles and causing relaxation of small arteries (12). Here, we have examined the effects of human CGRP-II on renal and cardiovascular functions in humans. Moreover, CGRP has been localized in rat kidneys, and rat CGRP was shown to stimulate renin secretion from isolated rat renal juxtaglomerular cells.

The results obtained suggest that CGRP may be involved in the physiological regulation of renin secretion by the peripheral nervous system.

\section{Methods}

Peptides. Synthetic human CGRP-II and rat CGRP $\alpha$ were purchased from Peninsula Laboratories, Belmont, CA. Over $90 \%$ of synthetic human CGRP-II and rat CGRP $\alpha$ eluted as single peaks on reversephase HPLC (5). Human CGRP-II was dissolved in $0.15 \mathrm{M} \mathrm{NaCl}$ and $0.1 \% \mathrm{HSA}$, and vials containing $6.6 \mathrm{nmol} / \mathrm{ml}$ were prepared under aseptic conditions by the University of Basel Hospital Pharmacy, Basel, Switzerland, and stored at $-20^{\circ} \mathrm{C}$. Synthetic human calcitonin (Cibacalcin) was donated by Ciba-Geigy Ltd., Basel, Switzerland.

In vivo studies. 10 healthy male volunteers received intravenous infusions of synthetic human CGRP-II at an initial rate of $1.2 \mathrm{pmol} / \mathrm{kg}$ per min, followed by $4.2 \mathrm{pmol} / \mathrm{kg}$ per min for $60 \mathrm{~min}$. For comparison, synthetic human calcitonin ( $4.2 \mathrm{pmol} / \mathrm{kg}$ per $\mathrm{min}$ ) was administered to five of the subjects receiving CGRP. The study has been approved by the Ethics Committee of the University of Bern Hospital, Bern, Switzerland, and informed consent was obtained from each subject investigated. Plasma renin activity, effective renal plasma flow, glomerular filtration fraction, arterial pressure, and heart rate were monitored before, during, and after the infusions. $0.9 \% \mathrm{NaCl}$ was infused at a rate of $1 \mathrm{ml} / \mathrm{min}$ for $240 \mathrm{~min} .1 .2 \mathrm{pmol} / \mathrm{kg}$ per min was added between 60 and $120 \mathrm{~min}$, and $4.2 \mathrm{pmol} / \mathrm{kg}$ per min CGRP-II was added between 120 and $180 \mathrm{~min}$. Plasma renin activity and aldosterone concentrations were measured by RIA (14). The arterial pressure was determined by an automatic device (Tonoprint; Speidel and Keller, Jungingen, FRG), and the heart rate by counting the radial pulse. Effective renal plasma flow and the filtration fraction were analyzed using a constant infusion technique of ${ }^{51} \mathrm{Cr}$-EDTA and paraminohippuric acid in bladder-catheterized subjects. Statistical analysis was done with the SASsoftware package (statistical analysis system, version 50; SAS Institute, Cary, NC) using an analysis of covariance and the $t$ test.

Renin release from isolated juxtaglomerular (JEG) cells. Primary cell cultures of rat JEG cells were prepared as single cell suspensions by perifusion of rat kidneys with citrate, dissociation with trypsin and collagenase, and sieving through a $22-\mu \mathrm{m}$ screen as described $(15,16)$. The cells were further separated on a $25 \%$ isoosmotic Percoll gradient, and cells with a density of $1.06 \mathrm{~g} / \mathrm{ml}$ were used for culture. On the second day of culture, $\sim 90 \%$ of the attached cells were JEG-cells, as judged from the specific immunostaining for rat renin (15). Determination of renin release from the cells was done by measuring the linear increase of renin activity of the cell supernatant in the absence and presence of rat CGRP and rat and salmon calcitonin, at 10,20, and 30 
min after the start of the experiments. The culture medium was replaced with prewarmed Hepes-buffered solution $(132 \mathrm{mM} \mathrm{NaCl}, 5$ $\mathrm{mM} \mathrm{KCl}, 0.8 \mathrm{mM} \mathrm{MgSO}_{4}, 2 \mathrm{mM} \mathrm{CaCl} 2,10 \mathrm{mM}$ sodium acetate, 2 $\mathrm{mM} \mathrm{NaH} \mathrm{PO}_{4}, 10 \mathrm{mM}$ glucose, and $20 \mathrm{mM}$ Hepes, $\mathrm{pH}$ 7.2). The culture dishes were then placed on a heating block at $37^{\circ} \mathrm{C}$, and the time-dependent increase of renin activity of the buffer was monitored. Renin activity was determined by its ability to generate angiotensin I from the plasma of bilaterally nephrectomized rats as described (16). At the end of the experiments, the cells were lysed by the addition of 1 $\mathrm{N} \mathrm{NaOH}$ and cellular protein was determined according to the method of Lowry (17).

cAMP measurements. For determination of the cellular cAMP content, the culture medium was replaced with the buffer used for the measurement of renin release, and the culture dishes were placed on a heating block at $37^{\circ} \mathrm{C}$. At the end of the incubations, the buffer was withdrawn and the dishes were placed on an ice block. Then, $0.4 \mathrm{ml}$ ice-cold buffer containing $5 \mathrm{mM}$ potassium phosphate, 2 mM EDTA, $0.5 \mathrm{mM}$ 3-isobutyl-1-methyl-xanthine (IBMX), and $150 \mathrm{mM} \mathrm{KCl}(\mathrm{pH}$ 6.8) were added, and the cells were scraped with a Teflon policeman. The cells were sonicated and boiled for $5 \mathrm{~min}$ and centrifuged. The supernatants were assayed for cAMP using a specific binding assay (18). The pellets were lysed with $1 \mathrm{~N} \mathrm{NaOH}$ and used for protein determination (17).

Immunohistochemistry. $50 \mathrm{mg} / \mathrm{kg}$ capsaicin was administered $1 \mathrm{wk}$ before killing and control rats (150-200 g body wt; ALAB, Stockholm, Sweden) received the vehicle alone. The rats were anesthetized with sodium pentobarbital $(50 \mathrm{mg} / \mathrm{kg} \mathrm{Nembutal})$, and perfused via the ascending aorta with Tyrode's solution, followed by picric acid containing formalin, and further processed as described (19). Immunofluorescence staining of rat renal cryosections was done as described in detail elsewhere (19). Antiserum to rat CGRP $\alpha$ was purchased from Peninsula Laboratories.

Extraction of CGRP. Pools of 10 rat kidneys obtained immediately after decapitation were used with the pelvis removed. The rest of the kidneys was minced and placed in $10 \mathrm{vol}$ of $2 \mathrm{M}$ acetic acid, and transferred to a boiling water bath for $5 \mathrm{~min}$. Subsequently, the tissues were homogenized for 5 min using an Ultra-Turrax homogenizer (IKA-Werk; Staufen, FRG), and the homogenates were centrifuged at $48,000 \mathrm{~g}$ for $30 \mathrm{~min}$ at $4^{\circ} \mathrm{C}$. Clear supernatants were adsorbed to octadecasilyl silica Sep-Pak C18 cartridges (Waters Associates, Millipore Corp., Milford, MA), and eluted with $60 \%$ (vol/vol) acetonitrile containing $0.1 \%$ trifluoroacetic acid as described (20). Lyophilized eluates were dissolved in solvent containing $20 \%$ acetonitrile and subjected to reverse phase HPLC with Nucleosil C18 using a linear gradient of acetonitrile (20-58\%). Effluent fractions were analyzed for immunoreactive CGRP (21) and calcitonin (22). The recovery ranged from 60 to $80 \%$.

\section{Results}

Human CGRP-II was intravenously infused in healthy human volunteers, and the results are summarized in Table I. Infusion of $4.2 \mathrm{pmol}$ CGRP-II $/ \mathrm{kg}$ per min caused an increase of the plasma renin activity $(P<0.05)$. The filtration fraction and the heart rate were also raised, whereas the diastolic arterial pressure and the effective renal plasma flow were lowered $(P$ $<0.05$ ). Plasma aldosterone levels were not consistently changed.

For comparison, we have also examined the effect of synthetic human calcitonin $(4.2 \mathrm{pmol} / \mathrm{kg}$ per $\mathrm{min})$ in 5 out of the 10 volunteers. Calcitonin at this dose did not alter the heart rate, arterial pressure, renal plasma flow, filtration fraction, and plasma aldosterone concentrations. A small increase of $17 \pm 15 \%$ (mean \pm SEM; $n=5$ ) in plasma renin activity was statistically not significant $(P>0.1)$.

A possible direct effect of rat CGRP on renin secretion was analyzed in isolated rat renal JEG cells (Fig. 1). There, rat CGRP caused a threefold stimulation of renin secretion (halfmaximal effective concentration $\left[\mathrm{EC}_{50}\right] 100 \mathrm{nM}$ ). In the rat hypocalcemia assay, rat calcitonin is less potent than salmon calcitonin. Along the same lines, rat calcitonin did not stimulate renin secretion, whereas salmon calcitonin was still much less effective than rat CGRP $\alpha$ in raising renin secretion. The stimulation of renin secretion by CGRP was paralleled by a transient increase $\left(\mathrm{EC}_{50} 80 \mathrm{nM}\right)$ of cellular cAMP levels (Fig. 2). The effect of CGRP on CAMP was enhanced in the presence of the phosphodiesterase inhibitor IBMX. The $\mathrm{EC}_{50}$ for cAMP production by CGRP (60 $\mathrm{nM})$ and for the stimulation of renin secretion (100 $\mathrm{nM})$ were similar. Stimulation of cAMP formation by CGRP $\alpha$ was not mediated by $\beta$-adrenoreceptors because the presence of the $\beta$-receptor antagonist, propranolol $(0.1 \mu \mathrm{M})$, did not affect CGRP $(0.01$ and $0.1 \mu \mathrm{M})$ stimulated cAMP formation.

To reveal possible sources of endogeneously released CGRP, kidney sections were processed for CGRP immunofluorescence histochemistry (Fig. 3). CGRP-immunoreactive

Table I. Effects of Intravenous Infusion of Human CGRP-II in Normal Human Volunteers $(n=10)$ on Plasma Renin Activity, Systolic and Diastolic Arterial Pressure, Heart Rate, Effective Renal Plasma Flow, and Filtration Fraction

\begin{tabular}{|c|c|c|c|c|}
\hline Infusion & Control & CGRP & CGRP & Recovery \\
\hline & & $1.2 \mathrm{pmol} / \mathrm{kg}$ per min & $4.2 \mathrm{pmol} / \mathrm{kg}$ per min & \\
\hline Time (min) & 50 & 110 & 170 & 230 \\
\hline $\mathrm{BP}_{\text {syst }}(m m H g)$ & $113 \pm 3$ & $111 \pm 3$ & $109 \pm 3$ & $112 \pm 3$ \\
\hline $\mathrm{BP}_{\text {diast }}(\mathrm{mmHg})$ & $59 \pm 2$ & $54 \pm 3$ & $45 \pm 3^{*}$ & $55 \pm 3$ \\
\hline $\operatorname{HR}\left(\right.$ min $\left.^{-1}\right)$ & $57 \pm 3$ & $62 \pm 3$ & $78 \pm 4^{*}$ & $62 \pm 2$ \\
\hline eRPF $(\mathrm{ml} / \mathrm{min})$ & $533 \pm 26$ & $453 \pm 18$ & $422 \pm 22^{\ddagger}$ & $516 \pm 42$ \\
\hline $\mathrm{FF}(\%)$ & $21.1 \pm 0.8$ & $21.7 \pm 1.1$ & $24.0 \pm 1.2^{\ddagger}$ & $21.2 \pm 0.9$ \\
\hline PRA $(n g / m l p e r h)$ & $1.45 \pm 0.08$ & $1.36 \pm 0.09$ & $1.98 \pm 0.28^{\ddagger}$ & $1.34 \pm 0.11$ \\
\hline Aldosterone $(\mathrm{pg} / \mathrm{ml})$ & $78.7 \pm 8.2$ & $54.5 \pm 3.4$ & $67.1 \pm 9.5$ & $53.3 \pm 4.6$ \\
\hline
\end{tabular}

$0.9 \% \mathrm{NaCl}$ was infused at a rate of $1 \mathrm{ml} / \mathrm{min}$ for $240 \mathrm{~min} .1 .2 \mathrm{pmol} / \mathrm{kg}$ per min CGRP-II was added between 60 and $120 \mathrm{~min}$, and $4.2 \mathrm{pmol} / \mathrm{kg}$ per min CGRP-II between 120 and 180 min. Values are means \pm SEM. ${ }^{*} P<0.01$ vs control period; ${ }^{*} P<0.05$. Abbreviations: BP, systolic and diastolic arterial pressure; eRPF, effective renal plasma flow; FF, filtration fraction; HR, heart rate; PRA, plasma renin activity. 


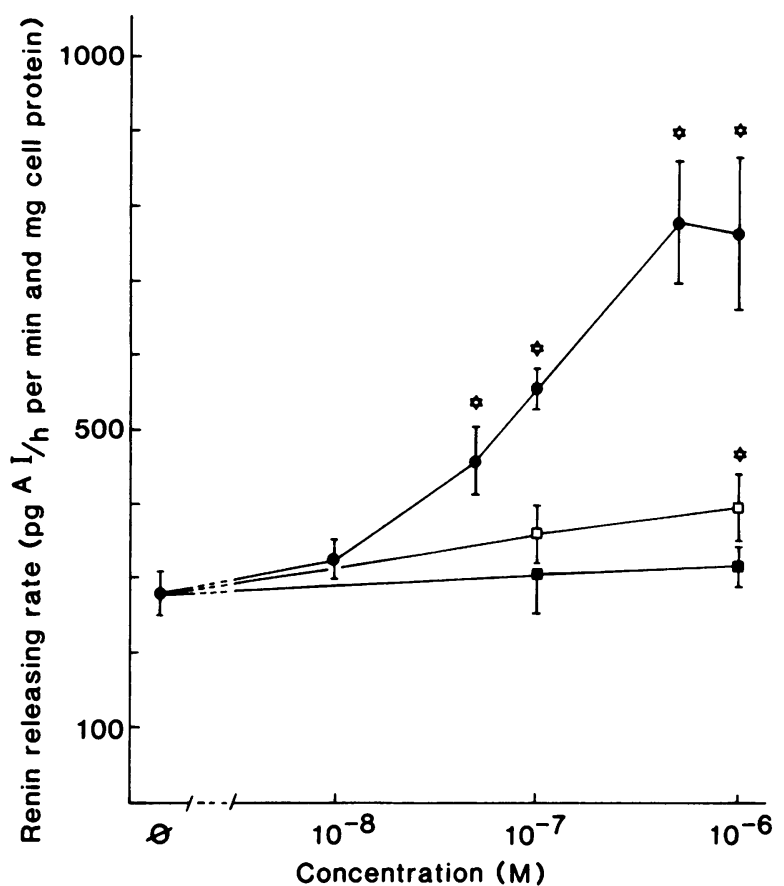

Figure 1. Effects of rat CGRP $\alpha$ and of rat and salmon calcitonin on the release of renin from isolated rat renal JEG epitheloid cells. Values are means $\pm \operatorname{SEM}\left(n=10\right.$ independent experiments). ${ }^{*} P$ $<0.05$ vs. control values. $\bullet$, rat CGRP; $₫$, rat calcitonin; $\square$, salmon calcitonin.

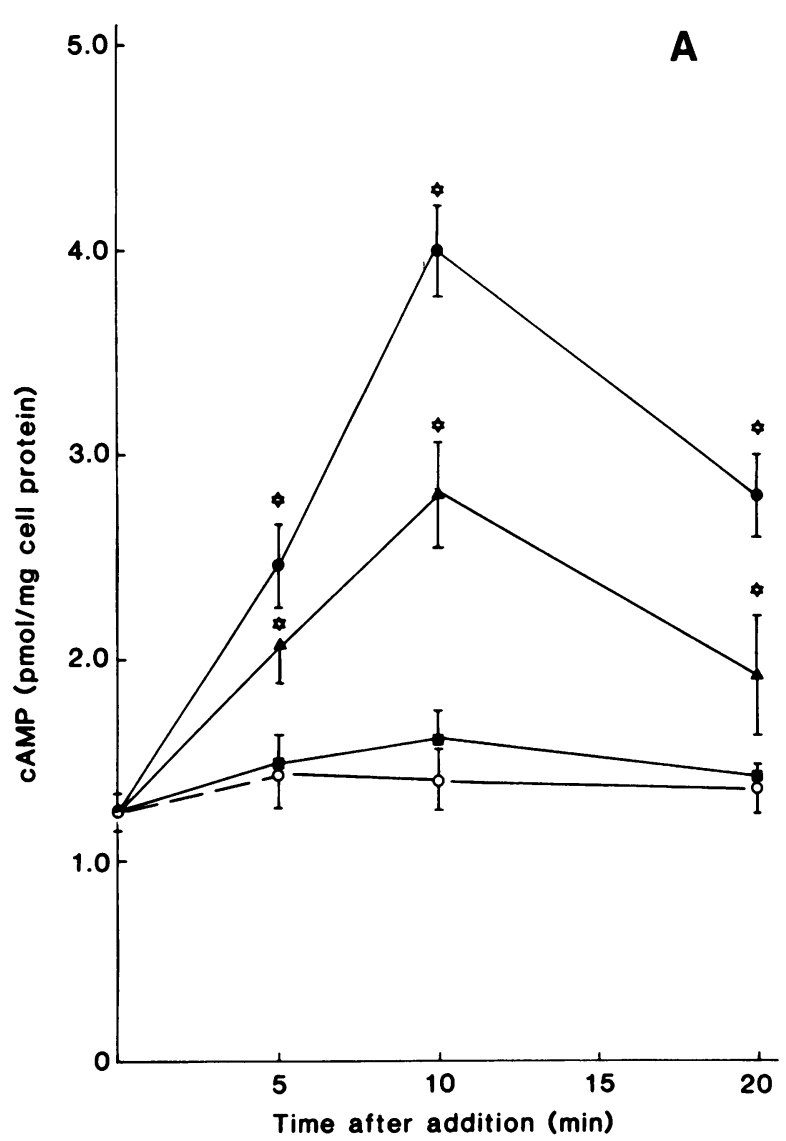

Figure 2. Effects of rat CGRP $\alpha$ on cellular cAMP levels in isolated rat JEG cells. cAMP content was measured as a function of the incubation time period in the absence of $\operatorname{IBMX}(A)$, and in the absence and presence of $0.5 \mathrm{mM}$ IBMX after incubation for $10 \mathrm{~min}(B)$. nerve fibers were visualized throughout the kidney. The densest innervation was seen within the smooth muscle layer in the pelvis and close to the epithelium (Fig. $3 A$ ). Many small arteries and arterioles received a prominent innervation (Fig. 3 $B)$. Some fibers could be followed into the parenchyma surrounding tubules without any apparent association with blood vessels (Fig. $3 C$ ). Thin and smooth varicose fibers were also seen close to the glomeruli with associated arterioles and JEG cells (Figs. $3 E$ and $F$ ). A marked decrease in the number of CGRP-immunoreactive nerve fibers around blood vessels was observed after treatment with capsaicin (Fig. $3 \mathrm{D}$ ). Immunofluorescence was obliterated by exposure of the sections to 1 $\mu \mathrm{M}$ rat $\mathrm{CGRP} \alpha$, but not to $1 \mu \mathrm{M}$ rat calcitonin.

Intact CGRP was, moreover, identified in extracts of the rat kidney cortex (Fig. 4). Immunoreactive CGRP had the retention time on HPLC of synthetic rat CGRP $\alpha$, whereas rat calcitonin was not detected.

\section{Discussion}

Here we have investigated the effects of CGRP on renin secretion. To this end, administration of CGRP-II to normal human volunteers caused a rise of plasma renin activity that indicates stimulation of renal renin secretion (Table I). An observed fall in renal plasma flow and a rise in filtration fraction are consistent with efferent arteriolar vasoconstriction, which may result from activation of the intrarenal renin-an-

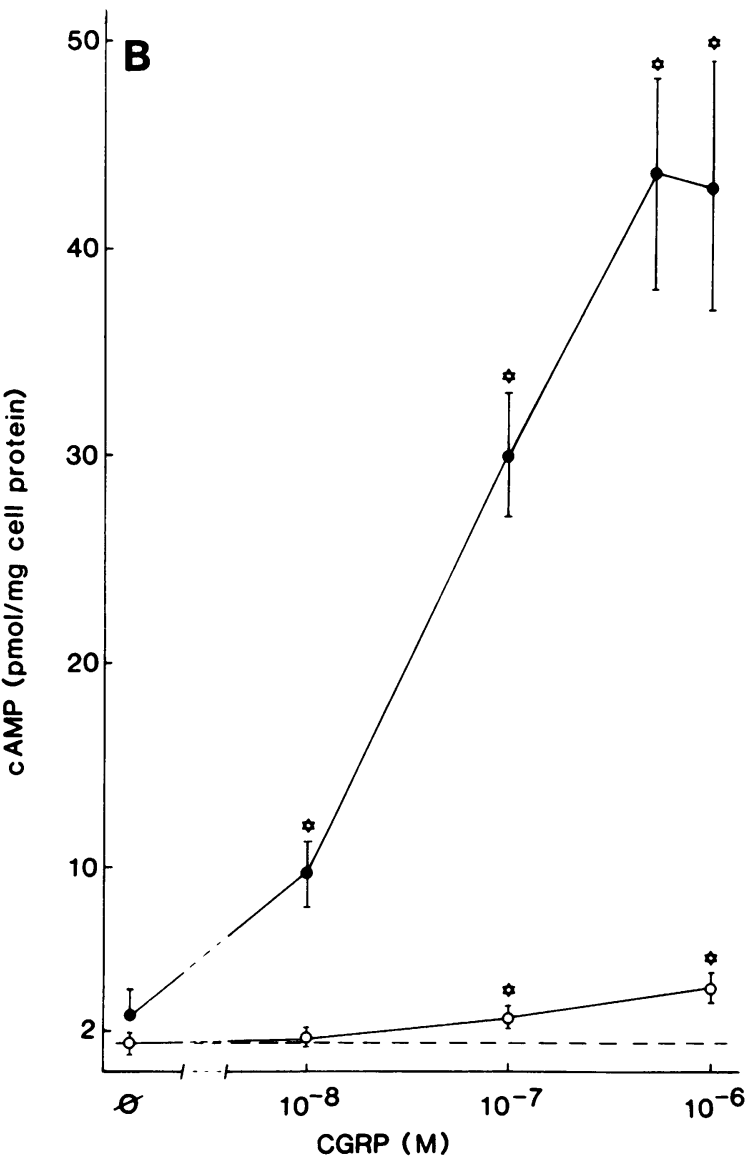

Values are means $\pm \operatorname{SEM}\left(n=6\right.$ experiments). ${ }^{*} P<0.05$ vs. control. In $A$, CGRP, in moles per liter: ०, $0 ; \bullet, 10^{-8} ; \Delta, 10^{-7} ; \bullet, 10^{-6}$. In $B$, , without IBMX; •, with $0.5 \mathrm{mM}$ IBMX. 

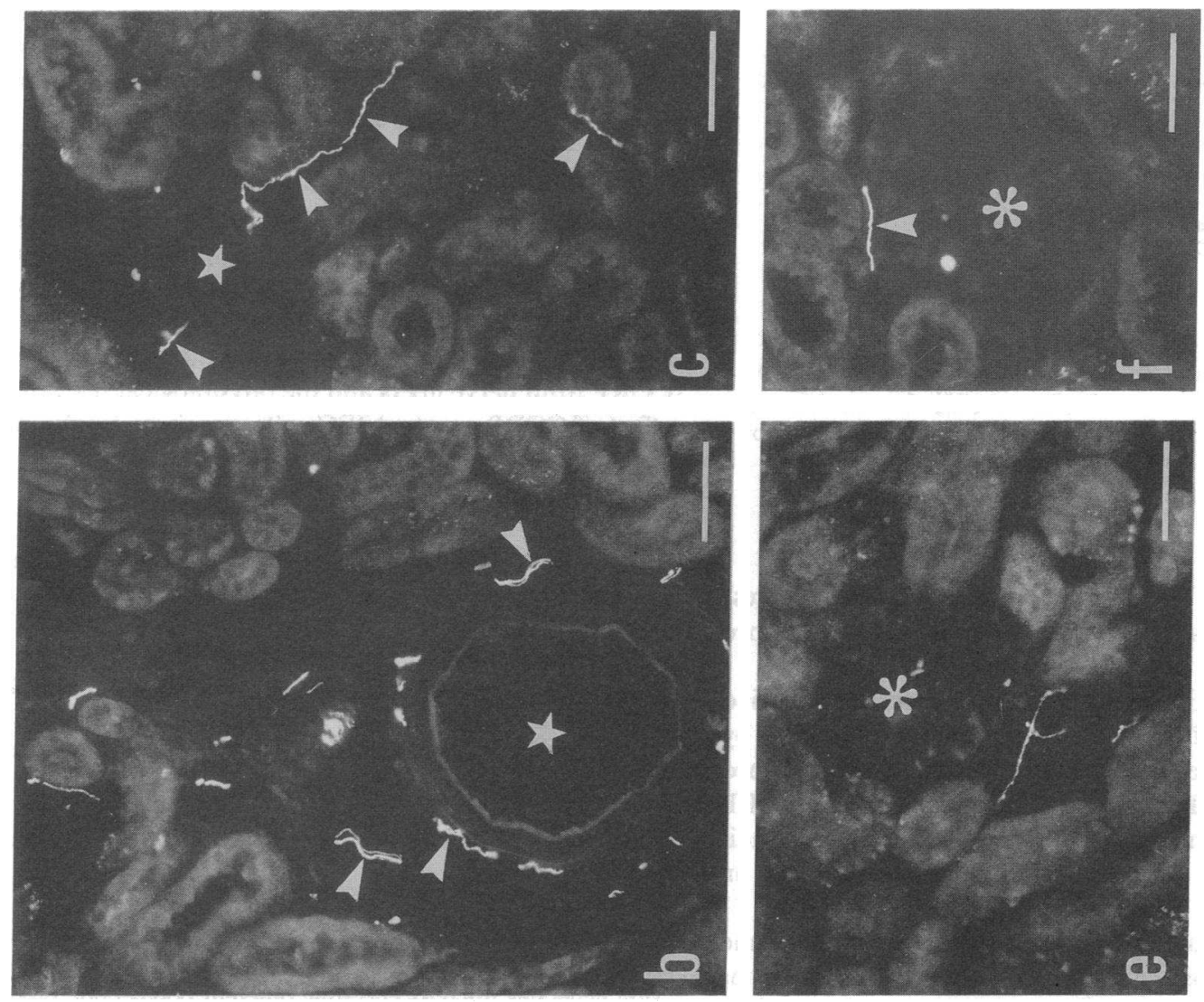

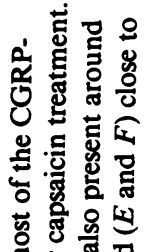

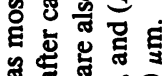

先

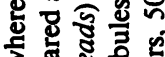

3 管

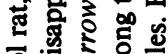

한

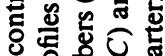

은 告 के 웅 政 总要 ฮㄴ. 若

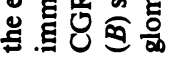
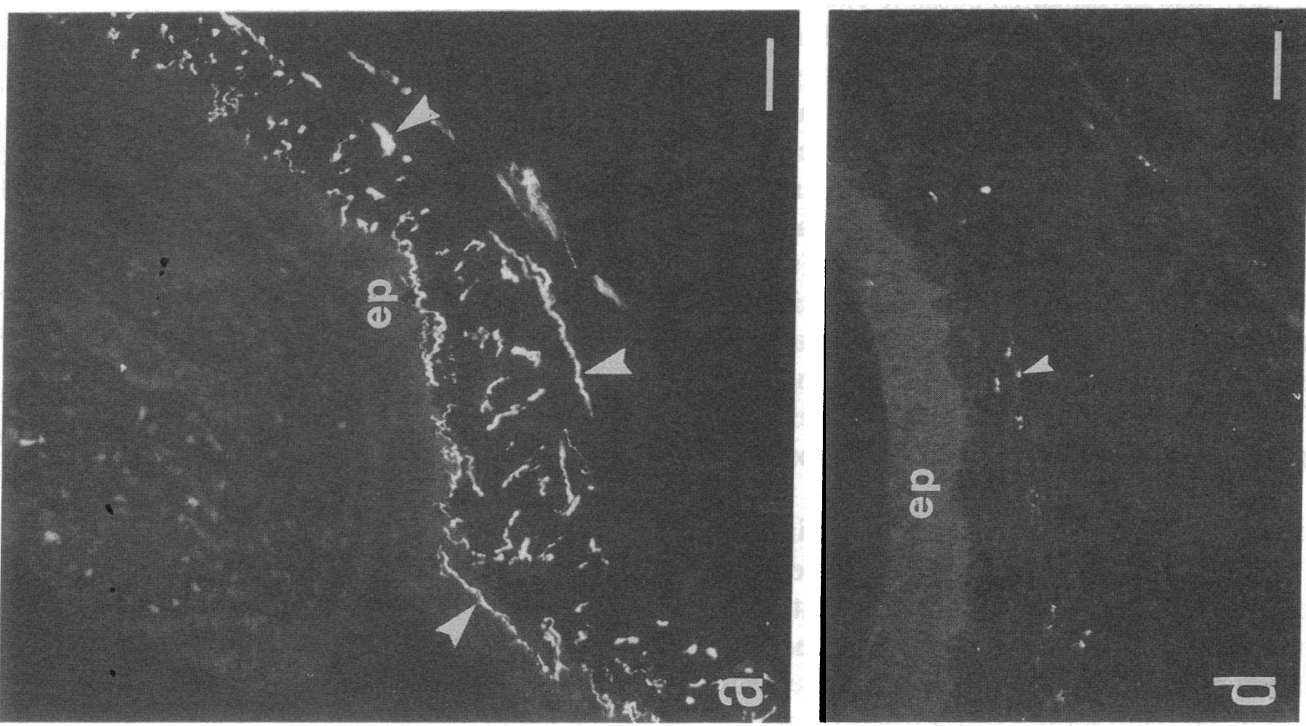

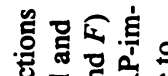
的 उ ज小 毛论 $\exists 1$ 屯 ธ 。

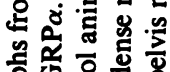
엉

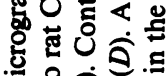

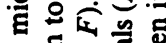
绕 娄 造 然 继记

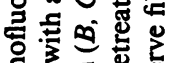

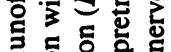
등.응 봉 的光 局 ․ㅡㅇ

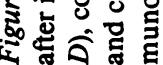




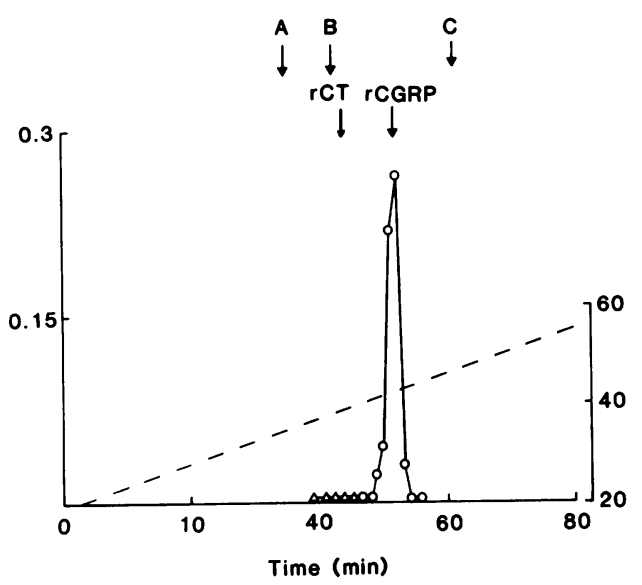

Figure 4. Reverse phase HPLC profile of immunoreactive CGRP (o) and calcitonin $(\Delta)$ extracted from rat kidneys. The sulfoxide form of $\left[{ }^{3} \mathrm{H}\right]$ substance $\mathrm{P}(A),\left[{ }^{3} \mathrm{H}\right]$ substance $\mathrm{P}(B)$, and $\left[{ }^{3} \mathrm{H}\right]$ salmon calcitonin $(C)$ were included as calibration markers. Arrows, retention times of synthetic rat CGRP $\alpha$ (rCGRP) and rat calcitonin ( $\mathrm{rCT}$ ) analyzed separately. $\circ, \mathrm{CGRP} ; \triangle, \mathrm{CT}$ pmol/g tissue. - - , $\% \mathrm{CH}_{3} \mathrm{CN}$.

giotensin system (23). The decrease in diastolic arterial pressure most likely reflects a fall of peripheral vascular resistance due to CGRP (8-12).

To test whether CGRP stimulates renin secretion in vivo indirectly as a result of the fall in arterial pressure (24), or by direct stimulation of renin-secreting cells, we have examined the effect of rat CGRP on isolated JEG cells. Here, CGRP caused a threefold stimulation of renin secretion, which indicates that CGRP may have a direct regulatory influence on JEG cells (Fig. 1).

In view of the structural homology between CGRP and calcitonin and the cross-tachyphylaxis observed between the two peptides (25-27), we have also investigated possible effects of rat and salmon calcitonin on renin secretion in vitro and in vivo. On a molar basis, CGRP was more active in stimulating renin secretion than salmon calcitonin, and rat calcitonin was inactive (Fig. 1). Our results thus confirm the recent observation that salmon calcitonin stimulates renin secretion in humans (28). Also in vivo, human calcitonin in equimolar amounts in relation to CGRP did not affect plasma renin activity. The findings suggest that CGRP, rather than calcitonin, interacts with receptors on JEG cells. The numerical similarity of $\mathrm{EC}_{50}$ values for CAMP production (Fig. 2) and the release of renin (Fig. 1) are consistent with a linkage between activation of adenylate cyclase by CGRP and renin secretion $(26,27,29,30)$.

cAMP is so far the best characterized mediator of renin secretion in JEG cells (31) and CGRP apparently stimulates the release of renin from the cells by activation of adenylate cyclase. The $\mathrm{EC}_{50}$ values of CGRP for renin secretion and adenylate cyclase activation are similar to those for the stimulation of the heart rate and the contractility of the rat atrium (26). However, the $\mathrm{EC}_{50}$ values were much higher than circulating levels of the peptide that have been reported to range from $<10$ to $100 \mathrm{pM}$ in normal human subjects $(32,33)$. The juxtaglomerular cells in situ may be exposed to higher local concentrations of CGRP released from nerves, much like in the heart and in blood vessels. In fact, we have identified CGRP, but not calcitonin in the renal cortex (Fig. 4).
Renin is synthesized, stored, and released from the JEG cells, which are localized in the wall of afferent arterioles just adjacent to the glomeruli. Using immunohistochemistry, CGRP-like immunoreactivity was localized in several regions of the kidney, including fibers in proximity of the juxtaglomerular apparatus. The presence of these fibers suggests that neuronally released CGRP acts directly on renin-secreting cells. From the observation that the CGRP immunoreactivity was decreased after capsaicin treatment, it may be inferred that immunoreactive nerves were of sensory origin (19).

Together, our findings provide strong evidence that CGRP is present in renal sensory nerve fibers near arterioles close to glomeruli. This may imply that CGRP is locally released and as a result increases the secretion of renin from the juxtaglomerular apparatus. CGRP may be involved in the physiological regulation of renin secretion by the peripheral nervous system. Physiological mechanisms controlling the release of CGRP from nerve fibers and the physiological relevance of the effect of CGRP on renal JEG cells remain to be clarified.

\section{Acknowledgments}

The authors wish to thank W. Gehret, R. Mosimann, E. Oldenberg, S. Schwenk, B. von Gunten, and I. Weissbrodt for their expert technical assistance.

These studies were supported by Swiss National Science Foundation grants 3.957-0.84 and 3.800-0.86, Swedish Medical Research Council grants 14X-6445 and 04X-2887, the Bissendorf Company, Wedemark/FRG, the American Tobacco Company, and the Swedish Tobacco Company.

\section{References}

1. Amara, S. G., V. Jonas, M. G. Rosenfeld, S. E. Ong, and R. M. Evans. 1982. Alternative RNA processing in calcitonin gene expression generates mRNAs encoding different polypeptide products. $\mathrm{Na}$ ture (Lond.). 298:240-244.

2. Rosenfeld, M. G., J. J. Mermod, S. G. Amara, L. W. Swanson, P. E. Sawchenko, J. Rivier, W. W. Vale, and R. M. Evans. 1983. Production of a novel neuropeptide encoded by the calcitonin gene via tissue-specific RNA processing. Nature (Lond.). 304:129-135.

3. Morris, H. R., M. Panico, T. Etienne, J. Tippins, S. I. Girgis, and I. MacIntyre. 1984. Isolation and characterization of human calcitonin gene-related peptide. Nature (Lond.). 308:746-748.

4. Steenbergh, P. H., J. W. M. Höppener, J. Zandberg, A. Visser, C. J. M. Lips, and H. S. Jansz. 1986. A second human calcitonin/ CGRP gene. FEBS (Fed. Eur. Biochem. Soc.) Lett. 209:97-103.

5. Petermann, J. B., W. Born, J. Y. Chang, and J. A. Fischer. 1987. Identification in the human central nervous system, pituitary and thyroid of a novel neuropeptide calcitonin gene-related peptide, and partial amino acid sequence in the spinal cord. J. Biol. Chem. 262:542545.

6. Mason, R. T., R. A. Peterfreund, P. E. Sawchenko, A. Z. Corrigan, J. E. Rivier, and W. W. Vale. 1984. Release of the predicted calcitonin gene-related peptide from cultured rat trigeminal ganglion cells. Nature (Lond.). 308:653-655.

7. Saria, A., R. Gamse, J. Petermann, J. A. Fischer, E. Theodorsson-Norheim, and J. M. Lundberg. 1986. Simultaneous release of several calcitonin gene-related peptides from rat spinal cord slices. Neurosci. Lett. 63:310-314.

8. Brain, S. D., T. J. Williams, J. R. Tippins, H. R. Morris, and I. MacIntyre. 1985. Calcitonin gene-related peptide is a potent vasodilator. Nature (Lond.). 313:54-56.

9. Fisher, L. A., D. O. Kikkawa, J. E. Rivier, S. G. Amara, R. M. Evans, M. G. Rosenfeld, W. W. Vale, and M. R. Brown. 1983. Stimu- 
lation of noradrenergic sympathetic outflow by calcitonin gene-related peptide. Nature (Lond.). 305:534-536.

10. Gennari, C., and J. A. Fischer. 1985. Cardiovascular action of calcitonin gene-related peptide in humans. Calcif. Tissue Int. 37:581584.

11. Struthers, A. D., M. J. Brown, D. W. R. MacDonald, J. L. Beacham, J. C. Stevenson, H. R. Morris, and I. MacIntyre. 1986. Human calcitonin gene-related peptide: a potent endogenous vasodilator in man. Clin. Sci. 70:389-393.

12. Franco-Cereceda, A., C. Gennari, R. Nami, D. Agnusdei, J. Pernow, J. M. Lundberg, and J. A. Fischer. 1987. Cardiovascular effects of calcitonin gene-related peptides I and II in man. Circ. Res. 60:393-397.

13. Hackenthal, E., and R. Taugner. 1986. Hormonal signals and intracellular messengers for renin secretion. Mol. Cell. Endocrinol. 47:1-12.

14. Sealey, J. E., S. Gerten-Banes, and J. H. Laragh. 1973. The renin system: variations in man measured by radioimmunoassay or bioassay. Kidney. Int. 1:240-253.

15. Kurtz, A., R. Della Bruna, J. Pfeilschifter, R. Taugner, and C. Bauer. 1986. Atrial natriuretic peptide inhibits renin release from juxtaglomerular cells by a cGMP mediated process. Proc. Natl. Acad. Sci. USA. 83:4769-4773.

16. Kurtz, A., J. Pfeilschifter, A. Hutter, C. Bührle, R. Nobiling, R. Taugner, E. Hackenthal, and C. Bauer. 1986. Role of protein kinase C in inhibition of renin release caused by vasoconstrictors. Am. J. Physiol. 250:C563-C571.

17. Lowry, O. H., N. J. Rosebrough, A. L. Farr, and R. J. Randall. 1951. Protein measurement with the Folin phenol-reagent. J. Biol. Chem. 193:265-275.

18. Brown, B. L., Ekins, R. P., and J. D. M. Albano. 1972. Saturation assay for cyclic AMP using endogeneous binding protein. In Advances in Cyclic Nucleotide Research. Vol. 2. P. Greengard and G. A. Robinson, editors. Raven Press, New York. 25.

19. Franco-Cereceda, A., H. Henke, J. M. Lundberg, J. B. Petermann, T. Hökfelt, and J. A. Fischer. 1987. Calcitonin gene-related peptide in capsaicin-sensitive substance P-immunoreactive sensory neurons in animals and man. Peptides (NY). 8:399-410.

20. Tobler, P. H., A. Jöhl, W. Born, and J. A. Fischer. 1982. Identity of calcitonin extracted from normal human thyroid gland with synthetic human calcitonin (1-32). Biochim. Biophys. Acta. 707:59-65.

21. Tschopp, F. A., P. H. Tobler, and J. A. Fischer. 1984. Calcitonin gene-related peptide in the human thyroid, pituitary and brain. Mol. Cell. Endocrinol. 36:53-57.
22. Fischer, J. A., P. H. Tobler, M. Kaufmann, W. Born, H. Henke, P. E. Cooper, S. M. Sagar, and J. B. Martin. 1981. Calcitonin: regional distribution of the hormone and its binding sites in the human brain and pituitary. Proc. Natl. Acad. Sci. USA. 78:7801-7805.

23. Hall, J. E., and J. P. Granger. 1983. Renal hemodynamic actions of angiotensin II: interaction with tubuloglomerular feedback. Am. J. Physiol. 245:R166-R173.

24. Davies, J. O., and R. H. Freeman. 1976. Mechanisms regulating renin release. Physiol. Rev. 56:1-56.

25. Fischer, J. A., and W. Born. 1985. Novel peptides from the calcitonin gene expression, receptors and biological function. Peptides (NY). 6(Suppl. 3):265-271.

26. Sigrist, S., A. Franco-Cereceda, R. Muff, H. Henke, J. M. Lundberg, and J. A. Fischer. 1986. Specific receptor and cardiovascular effects of calcitonin gene-related peptide. Endocrinology. 119:381389.

27. Roos, B. A., J. A. Fischer, W. Pignat, C. B. Alander, and L. G. Raisz. 1986. Evaluation of the in vivo and in vitro calcium-regulating actions of noncalcitonin peptides produced via calcitonin gene expression. Endocrinology. 118:46-51.

28. Malatino, L. S., C. E. Fiore, R. Foti, F. Guzzardi, and G. Tamburino. 1987. Acute effects of salmon calcitonin in man include stimulation of the renin-angiotensin-aldosterone system. Miner. Electrolyte Metab. 13:316-322.

29. Kubota, M., J. M. Moseley, G. J. Dusting, P. S. MacDonald, and T. J. Martin. 1985. Calcitonin gene-related peptide stimulates cyclic AMP formation in rat aortic smooth muscle cells. Biochem. Biophys. Res. Commun. 132:88-94.

30. Edvinsson, L., B. B. Fredholm, E. Hamel, I. Jansen, and C. Verrechia. 1985. Perivascular peptides relax cerebral arteries concomitant with stimulation of cyclic adenosine monophosphate accumulation independent of release of an endothelium-derived relaxing factor in the cat. Neurosci. Lett. 58:231-217.

31. Churchill, P. C. 1985. Second messengers in renin secretion. Am. J. Physiol. 249:F175-F184.

32. Girgis, S. I., D. W. MacDonald, J. C. Stevenson, P. J. Bevis, C. Lynch, S. J. Wimalawansa, C. H. Self, H. R. Morris, and I. MacIntyre. 1985. Calcitonin gene-related peptide: potent vasodilator and major product of calcitonin gene. Lancet. ii:14-16.

33. Mason, R. T., A. Shulkes, J. D. Zajac, A. E. Fletcher, K. J. Hardy, and T. J. Martin. 1986. Basal and stimulated release of calcitonin gene-related peptide (CGRP) in patients with medullary thyroid carcinoma. Clin. Endocrinol. 25:675-685. 